\title{
Perceptions of Ethics in Business: A Study of Business Students
}

\section{in Bangladesh}

\author{
Bishnu Kumar Adhikary ${ }^{1 *} \&$ Ranjan Kumar Mitra ${ }^{2}$ \\ ${ }^{1}$ Graduate School of Business Administration, Kobe University, Kobe, Japan \\ ${ }^{2}$ Department of Accounting and Information Systems, Dhaka University, Dhaka, Bangladesh \\ *Bishnu Kumar Adhikary, E-mail: bishnu_adhikary@people.kobe-u.ac.jp
}

\begin{abstract}
This paper uses a survey instrument to elicit business students' perceptions of ethics in business in Bangladesh. Based on students' opinions, the survey results show that ethical practices are not properly followed by companies in recruitment and managerial decision making. Also, most of the companies do not provide a safe and a harassment-free environment, especially for the female employees. Respondents further believe that the enactment of proper laws and regulations, religious values, and a well-defined code of conducts can play a significant role in improving ethical business practices in Bangladesh. Moreover, a good understanding of what constitutes ethical behavior by both managers and owners help promote ethical conducts. The paper suggests that a university should include different business courses on ethics in its academic curriculum to shape the ethical attitudes of the students properly.
\end{abstract}

\section{Keywords}

business ethics, students' perception, University, Bangladesh

\section{Introduction}

Over the last two decades, the term "business ethics" has received considerable attention by both academics and business communities as a way of addressing increased corporate frauds and unethical conducts. Business ethics can be viewed as a set of moral rules or norms of behavior of conducting business operations in a fair and equitable manner. In other words, business ethics is "the subjective assessments by a given individual with respect to sets of premises that make up various business philosophies" (Preble \& Reichel, 1988). Business ethics prevents irregularities and safeguard public and private trust in the absence of prudent regulations and effective market forces. Also, business ethics protects owners' interest, reduces agency conflicts and increases investors' confidence. Unfortunately, emerging economies often have regulatory loopholes and weak market forces that incentivize managers to disregard intentionally the social responsibilities of a business and to build their empires. Bangladesh, being an emerging economy, has been no exception. In fact, ethical violations in family members, government officials, and private workplaces have become a conspicuous feature of the contemporary 
landscapes in Bangladesh. For example, Transparency International Bangladesh (TIB) estimates that Bangladesh loses nearly $\$ 2.30$ billion dollars, almost $2.4 \%$ of its gross domestic product, to corruption every year (TIB, 2015). Similarly, World Bank (2013) notes that 47.7\% firms in Bangladesh experience bribery incidence for running their enterprises smoothly. Also, according to the World Bank's Ease of Doing Business Index 2015, Bangladesh falls under the bottom level (174 out of 189 countries) economies, indicating higher transaction cost and hazards for doing business in Bangladesh.

Notably, business and society are mutually interdependent, and a symbiotic relationship exists between them. Society depends on business for the creation of wealth, and the development of business depends on the environment where it can grow and create that wealth. Also, the actions of business leaders create impact not only on themselves but also to the customers, employees, investors, suppliers, governments, citizens, and communities as a whole. Thus, business is entrusted to faithfully and ethically exercise its responsibilities in the use of power. In practice, however, business managers often intentionally or obligatory compromise ethics against profits and build their empires. Recent scandals by some corporate stalwarts such as Enron, WorldCom, Arthur de Anderson, and Satyam Computer prove that managers can deceive stakeholders and act willfully for increasing their wealth. Thus, to ensure ethical conducts of the business leaders in the future, a study on the perceptions of business students, inter alia, towards ethics deserves attention. This is because today's students become the future leaders of businesses, and their ethical conducts greatly depend on the factors that they think ethical in student lives. On this tune, Mintz (1997) notes that introduction of a course on ethics in business education helps managers' to take an ethical decision. Likewise, Coutu (2006) states that the business students are likely to be more familiar with business ethics than the non-business students. The American Accounting Association also advocates for including a course on ethics in the accounting education to control future ethical lapses.

Given the above, this paper studies students' perceptions of ethics in business in Bangladesh. In doing so, the study interviews 155 final year students of the Faculty of Business Studies, University of Dhaka, by using a structured questionnaire. The choice of business students, particularly from Dhaka University, is taken into account for twin reasons. First, Business Faculty of the University of Dhaka has been providing quality education over a long period. Usually, students of this faculty join in reputable business firms or become entrepreneurs after graduation. Second, they are believed to be accumulated sufficient knowledge on contemporary ethical practices in Bangladesh through textbooks, group discussions, and media. So, their opinions can be a mirror of the future ethical business practices in Bangladesh as they are likely to be working as a business manager or become an entrepreneur. Also, the study expects to add knowledge in South Asian economies as there is hardly any study found so far that investigated students' perceptions of ethics in business in Bangladesh.

The key findings of the study are as follows. First, religious values can play a significant role in the perfection of ethical practices in Bangladesh, besides the well-defined code of conducts and enactment of laws and regulations. Second, management takes stern action against unethical practices as soon as 
they are reported and proved. However, it is unclear whether compliance with legal requirements promotes ethical behavior. Third, knowledge of business ethics for the owners and managers is essential to curve unethical practices, indicating the importance of introducing different courses on business ethics in the university curriculum. Fourth, most of the companies do not follow fair policies in recruitment. Also, they do not provide a safe and a harassment-free environment, especially for females. Fifth, most of the business people engage in malpractices intentionally not by competition or pressure from market forces. Finally, managers tend to publicize untrue, fabricated and exaggerated information about their products through advertisements in media to capture the market.

These findings, however, are not free from certain limitations. The study surveyed only 155 students who were in the final year at the Faculty of Business, the University of Dhaka. Dhaka University is the apex public university in Bangladesh regarding the quality of education and research. Thus, the students are expected to provide rational responses. However, the inclusion of a large number of students in the study may generate a bit different result from what this paper has obtained. Also, the study did not include students from private universities. Students of private universities may provide contradictory results since the environment of a private university is not the same as of the public university. Notably, this study does not intend to portray real business practices; rather it focuses on how business students of a premier educational institution perceive the activities of business organizations from ethical perspectives.

The remainder of the paper is organized as follows. Section 2 discusses prior studies on business ethics while Section 3 outlines research methods. Section 4 presents results of the study. Section 5 concludes with some policy implications.

\section{Literature Review}

Empirical works on students' perceptions of business ethics are not voluminous, but growing quickly. For example, Hollon and Ulrich (1979) find that students have lower personal ethics than executives. Miesing and Preble (1985) conclude that older and experienced people appear to be more ethical than students. Preble and Reichel (1988) find that both the American and Israeli business students put considerable importance on ethics in business. Likewise, Small (1992) indicates that students from Western Australia, Israel, and the USA have high commonality in viewing business ethics. He further notes that such commonality, perhaps, led business ethics and business practices to be very similar throughout the Western world.

As regards to the comprehension of ethics by disciplines of study, Hosmer (1999) unveils that accounting and finance students tend to consider business ethics and social responsibilities more important compared to other disciplines. Kerr and Smith (1995) further note that accounting students regard ethics as the main subject of business without which accounting profession miscarries. By the same token, Lumsden and Fatoki (2013) find that business students have more favorable attitudes towards business ethics than non-business students. As good ethical practices are vital to achieving 
success in business, they also note that non-business students need to improve their attitudes towards business ethics to become a successful entrepreneur. Alam (1995) concludes that Malaysian business students consider profits as the main task of a manager against any other goals. Besides, Malaysian students believe that a conflict exists between the corporate and the individual ethical conducts. In particular, ethical and moral considerations are ignored in selecting accounting policies in Malaysian organizations. Alam further notes that the ethical values of the companies in Malaysia declined during the last few years because of the lack of ethical education and top management's reluctance to exercise proper ethics. Similarly, Ma (2013) note that Chinese business students consider the ethicality of an action is important than its practicality in the real business world. Ahmed et al. (2003) conclude that students who have an idealistic attitude towards social responsibility and ethics perceive the magnitude of the ethical problems in a more facile way than others. Fischer and Rosenzwig (1995) note that accounting students tend to be more idealistic against other students to being ethical on earnings management. Similarly, Peppas and Diskin (2001) compare the attitudes of business students at two different periods, 1998 and 2002, and find that business students' attitudes towards ethics remain consistent over time. By contrast, Frank et al. (1993) conclude that economics students become increasingly self-interested as they progress through their academic program.

However, Curren and Harich (1996) find that a student's discipline of study (either business or humanities) does not matter in ethical judgments. Ludlum and Moskalionov (2003) note that students specialized in business do not differ significantly from the non-business majors on ethical issues. Reiss and Mitra (1998) also argue that the choice of majors has a little influence on workplace behavior. Besides, Abdolmohammadi et al. (1997) find that, on average, there is no significant difference in ethical cognition between the business students and the non-business students seeking admission at the college level. Cole and Smith (1996) unveil that business people and college students do not diverge significantly on adopting ethical practices in business. In fact, both demonstrate a high level of ethical beliefs. On the other hand, Lopez et al. (2005) argue that business school education expects to improve ethical beliefs of the Asian and Hispanic students in comparison to the Anglo-American students. However, Chung et al. (2008) state that the USA students are much more attuned to the need for ethical behavior in business.

Importantly, in Newsweek, Zeman (1989) reports results of a survey in which 1,093 high school seniors are asked by The Pinnacle Group, Inc., an international public relations corporation, to opine whether they could see themselves violating ethical principles to get ahead in the business world. Surprisingly, nearly $66 \%$ of the respondents opine that they would lie to achieve a business objective. An equal percentage also says that they would inflate their business expense reports. Besides, nearly $59 \%$ of these students show a willingness to face a six months' probation on an illegal deal in which they can earn \$10 million. Likewise, in 1992, Josephson Institute for Ethics reports results of a two-year study that included 3,630 college students from all regions of the USA. The report reveals that nearly $33 \%$ of the college students wish for lying to get a job, whereas $20 \%$ like to falsify a report or adopt an unfair 
means to keep their job intact. Similarly, in a study of upper-division business students from the five state universities across the USA, Roderick et al. (1991) find that $63 \%$ of the students like to steal from their employers. Besides, nearly 33\% students want to be involved in an illegal act if it helps them or their companies to earn more than $\$ 100,000$ profit, and there is a $1 \%$ chance of being caught and sent to a minimum of one-year prison for conducting such an act.

As for the differences between male and female students on ethical beliefs and behavior, Beltramini et al. (1984) conclude that females are significantly more concerned than males on ethical issues. Likewise, Cohen et al. (1998) find that women view doubtful actions to be more non-ethical than men. Similarly, Miesing and Preble (1985) unveil that females with religious convictions become more ethical than males with a little religious conviction. Smith and Rogers (2000), and Barnett and Karson (1989) further argue that, in the workforce, females perceive more ethical problems than males. Females also behave more ethically than males because females are likely to be more involved with a moral referent group than males. On the contrary, McNichols and Zimmerer (1985) find no significant difference in the ethical beliefs of males and females. Also, Robin and Babin (1997) report that there is no ethical difference between male and female professionals.

Concerning students' perceptions of codes of ethics, Desplaces et al. (2007) argue that ethical culture of an organization influences students' perceptions of ethics. If organization enforces a code of ethics properly, students consider those codes effective and place the higher moral obligation to follow them in daily works. Arlow and Ulrich (1988) find that business graduates view codes of conduct as the most effective way for corporate to improve business ethics. Shurden et al. (2010) conclude that perceptions of ethics by students change over time. Thus, the introduction of ethical courses in education positively shapes students ethical conducts. On the contrary, O'Clock and Okleshen (1993) note that "ethics is personal" and it mainly rests on the individualized set of ethical standards.

To conclude, academic literature on students' perceptions of business ethics is not confirmative rather contradictory. Ludlum et al. (2013) note that ethics is not a uniform concept except at the extreme level like everyone condemns murder. Ethical practices vary by countries, regions, social customs and traditions, cultural expectations, code of ethics, religions, rule of justice, and time. Given that the business students today are the business leaders of tomorrow, coupled with negative stereotypes surrounding them, attitudes of business students towards ethics tend to form largely a country's future ethical behavior. To this tune, a study on students' perceptions of business ethics in Bangladesh is indeed important.

\section{Methods}

The study is conducted on the $4^{\text {th }}$-year students of the Faculty of Business Studies at the University of Dhaka. The Faculty of Business Studies has eight departments that provide business-related knowledge with a specialization. The study adopted survey method with a structured questionnaire consisting of 16 questions to elicit students' opinions on business ethics in Bangladesh from all these departments. 
Participation in the survey was voluntary, and no remuneration was offered in answering the questions. The questionnaire was distributed unevenly. Thus, the number of respondents from each department was not the same. The participation of male and female was also not maintained at the same ratio. The students were asked to put their opinions on a Likert's 5-point scale as: strongly agreed (5), agreed (4), neutral (3), disagreed (2), and strongly disagreed (1) on the questions stated in the questionnaire. A total number of 200 questionnaires were distributed among the students, of which 155 answered all the questions. Table 1 summarizes students' responses by departments and genders.

Table 1. Department-Wise Number of Respondents, Gender, and Percentages

\begin{tabular}{clcccc}
\hline No. & \multicolumn{1}{c}{ Department } & Male & Female & Total & Percentage (\%) \\
\hline 1 & Accounting \& Information & & & & \\
& Systems & 32 & 22 & 54 & 34.84 \\
2 & Finance & 21 & 6 & 27 & 17.42 \\
3 & Marketing & 22 & 9 & 31 & 20.00 \\
4 & Management & 5 & 5 & 10 & 6.45 \\
5 & Banking & 2 & 2 & 4 & 2.58 \\
6 & Management Information & & & & \\
& Systems & 4 & 0 & 4 & 2.58 \\
7 & International Business & 8 & 4 & 12 & 7.74 \\
8 & Tourism and Hospitality & & & & \\
& Management & 6 & 7 & 13 & 8.39 \\
& Total (\%) & 100 & 55 & 155 & 100.00 \\
& & $(64.52 \%)$ & $(35.48 \%)$ & $(100 \%)$ & \\
\hline
\end{tabular}

The analysis of information proceeds as follows. First, opinions of the respondents are summarized into the three categories: strongly agreed or agreed, neither agreed nor disagreed, and disagreed or strongly disagreed. If the majority of the respondents become agreed or strongly agreed to a particular ethical factor, it is concluded that such factor positively influences students' ethical behavior and vice versa. Second, an overall mean score, the males' mean score, and the females' mean score are calculated for each of the statements to compare males' and female's mean scores with the overall mean score. Third, a t-test is conducted against the null hypothesis that the students are neutral in their opinion, or they do not have a definite positive or negative attitude towards a particular ethical factor. If the p-value of the t-statistic falls within a $5 \%$ level of significance, it is confirmed that the overall mean score is significantly different from three (3) that indicates middle-of-the-ground position. It also suggests that the students have a decisive opinion towards a particular ethical issue. Another t-test is also performed to check whether males and females students have meaningful differences in their opinions. 


\section{Results and Discussion}

Table 2 provides results of the survey according to the three categories of responses: strongly agreed or agreed, neither agreed nor disagreed, and disagreed or strongly disagreed. According to the Table 2, the key findings of the students' perceptions of business ethics are as follows. First, students believe that enterprises that are largely involved with societal causes behave more ethically over others in running the business (74.19\%). Also, companies with a well-defined code of conducts behave more ethically than companies without it (83.22\%). However, it is not clear whether the business people entrusted with decision-making take a true and a fair decision as only $36.78 \%$ of the respondents believe that decisions of the management are honest, fair and trustworthy. This may be because in Bangladesh, usually, the decision-making at the corporate level is influenced by political connections and references from influential bodies. Besides, approximately $56 \%$ of the students believe that management takes stern action against unethical practices as soon as they are reported and proved. Second, the majority (76.13\%) of the students believe that adherence to ethical practices adds profit to the firm. They also believe that a strict adherence to the laws and regulations can ensure ethical behavior of a corporation. This implies that business people may not comply with the ethical guidelines at all stages of business unless there are mechanisms put in place to ensure strict maintenance of ethical behavior. In addition, students tend to be confused on the issue whether the compliance of legal requirements is more important than showing ethical behavior as only $40 \%$ of the students agree that compliance with the legal requirements is more important than anything else. Such confusion may arise from the belief that compliance with the legal requirements itself is an execution of ethical behavior. Third, almost $93 \%$ of the students respond that religious values can largely influence the ethical behavior of a corporation. This may be attributed to the fact that ethical values are self-driven whereas unethical behaviors are the result of financial and non-financial greeds of the individuals. Hence, such greeds can be controlled by checking individuals own beliefs and instituting religious values among individuals working in a firm. Fourth, $47.74 \%$ of the students think that enterprises engage in malicious practices by intention, not by the pressure from market forces. This further indicates that malpractices are not the obligatory actions to survive the organization rather they are cunning strategies of the management to make a profit. On the other hand, $94.19 \%$ of the respondents believe that appropriate knowledge of ethics of the managers and employees can uphold the ethical behavior of an organization significantly, meaning that although the ethical behavior is a relative term, it can be excelled through an individual's proper knowledge of ethics and owned values. Fifth, students do not have a consensus on introducing courses on ethics to change their moral outlooks. Only, $41.94 \%$ of the students opine that a positive relationship exists between the courses on ethics and the changes in students' moral outlooks. This finding is contradictory with the previously mentioned one where students put more emphasis on the knowledge of business ethics in mitigating the ethical dilemma. This contradiction indicates that knowledge of ethics gleaned from religion, family values or societal norms at a younger stage of lives has a dominant impact on forming moral attitude than ethical learning obtained from formal education at the university level. 
Further research with larger sample size may generate more concrete evidence on this issue. Sixth, majority of the students (56.13\%) believe that companies favor nepotism in recruiting candidates. Also, $85.81 \%$ of the students respond that offering a gift or a bribe to secure a business contract is unethical. As for the use of natural resources, however, $32.90 \%$ of the respondents believe that enterprises view natural resources as free and unlimited goods available for use, whereas $52.26 \%$ do not agree with this belief. This is because enterprises may receive some natural resources as free goods but in most of the cases they need to pay to avail them. Seventh, students (52\%) believe that companies discriminate employees by gender, and they are reluctant to provide a safe and a harassment-free environment for female workers. Moreover, $75.48 \%$ of respondents believe that enterprises publish cooked information or exaggerate information to keep hold their market shares or to combat competition. This also implies that business students of Bangladesh poorly or negatively perceive the promotional activities of the business firms in Bangladesh.

Table 2. Students' Responses on Ethics for Sample Questions

\begin{tabular}{|c|c|c|c|}
\hline Question & $\begin{array}{l}\text { Strongly } \\
\text { Agreed or } \\
\text { Agreed }\end{array}$ & $\begin{array}{l}\text { Neither } \\
\text { Agreed or } \\
\text { Disagreed }\end{array}$ & $\begin{array}{l}\text { Disagreed } \\
\text { or Strongly } \\
\text { Disagreed }\end{array}$ \\
\hline Greater business involvement with societal causes bears & 115 & 18 & 22 \\
\hline testimony to ethical behavior. & $(74.19 \%)$ & $(11.61 \%)$ & $(14.20 \%)$ \\
\hline $\begin{array}{l}\text { Companies with a well-defined code of business conduct will } \\
\text { showcase more ethical behavior than companies without it. }\end{array}$ & $\begin{array}{c}129 \\
(83.22 \%)\end{array}$ & $\begin{array}{c}15 \\
(9.68 \%)\end{array}$ & $(7.10 \%)$ \\
\hline $\begin{array}{l}\text { Business people entrusted with decision-making are honest, fair, } \\
\text { just and trustworthy. }\end{array}$ & $\begin{array}{c}57 \\
(36.78 \%)\end{array}$ & $\begin{array}{c}42 \\
(27.10 \%)\end{array}$ & $\begin{array}{c}56 \\
(36.12 \%)\end{array}$ \\
\hline $\begin{array}{l}\text { Management takes stern action against unethical practices as } \\
\text { soon as these are reported and proved. }\end{array}$ & $\begin{array}{r}87 \\
(56.13 \%)\end{array}$ & $\begin{array}{c}32 \\
(20.65 \%)\end{array}$ & $\begin{array}{c}36 \\
(23.22 \%)\end{array}$ \\
\hline Adherence to ethical practices does not add profit to a firm. & $\begin{array}{c}21 \\
(13.54 \%)\end{array}$ & $\begin{array}{c}16 \\
(10.33 \%)\end{array}$ & $\begin{array}{c}118 \\
(76.13 \%)\end{array}$ \\
\hline $\begin{array}{l}\text { Ethical behavior can be ensured by strict adherence to laws and } \\
\text { regulation. }\end{array}$ & $\begin{array}{c}110 \\
(70.96 \%)\end{array}$ & $\begin{array}{c}06 \\
(3.87 \%)\end{array}$ & $\begin{array}{c}39 \\
(25.17 \%)\end{array}$ \\
\hline $\begin{array}{l}\text { Compliance with legal requirements is more important than } \\
\text { showing ethical behavior. }\end{array}$ & $(40 \%)$ & $\begin{array}{c}33 \\
(21.29 \%)\end{array}$ & $\begin{array}{c}60 \\
(38.71 \%)\end{array}$ \\
\hline $\begin{array}{l}\text { The religious values can play an important role in the conception } \\
\text { and perfection of business ethics. }\end{array}$ & $\begin{array}{c}144 \\
(92.90 \%)\end{array}$ & $\begin{array}{c}08 \\
(5.16 \%)\end{array}$ & $\begin{array}{c}03 \\
(1.94 \%)\end{array}$ \\
\hline $\begin{array}{l}\text { Businesses engage in corruption, malpractice, and immoral } \\
\text { activities by force (Intense competition, unreasonable target, } \\
\text { taking control of scarce resources), not by will. }\end{array}$ & $\begin{array}{c}48 \\
(30.97 \%)\end{array}$ & $\begin{array}{c}33 \\
(21.29 \%)\end{array}$ & $\begin{array}{c}74 \\
(47.74 \%)\end{array}$ \\
\hline
\end{tabular}


Knowledge of business ethics is very important for the owners and managers of the businesses and the future business leaders also.

Business students are unlikely to change their moral outlook because they took an ethics course.

The recruitment policy of the companies employs nepotism and favoritism in selecting candidates.

Offering a gift or bribe to secure a business contract is not unethical.

Businesses view natural resources (Air, Water, Land and other resources) as free and unlimited goods available for their use.

Companies do not make gender discrimination and provide safe and harassment free environment for female workers.

Businesses publicize untrue, fabricated and exaggerated information about their product through an advertisement in media.
146

04

05

$(94.19 \%) \quad(2.58 \%)$

55

35

65

$(35.48 \%)$

87

$(22.58 \%)$

$(41.94 \%)$

$(56.13 \%)$

43

25

15

(27.74\%)

(16.13\%)

$9.67 \%$

07

133

51

(4.52\%)

$(85.81 \%)$

23

81

$(32.90 \%)$

$(14.84 \%)$

39

35

(25.16\%)

(22.58\%)

$(52.26 \%)$

117

26

12

$(75.48 \%) \quad(16.77 \%)$

$(7.75 \%)$

Table 3 reports mean scores and the t-test results of the ethical questions asked to the students. As is observed in Table 3, students tend to have a definite opinion on certain issues such as well-defined code of business conducts, prompt actions against unethical practices, adherence to laws and regulations, religious values, compliance with legal requirements, and knowledge of business ethics to excel ethical behavior, as the mean score of all these factors exceeded the benchmark average score there (3). Besides, the t-test statistics reveal that opinions of the females and males students do not differ significantly on those ethical issues although females have a higher average score over males in certain cases. Likewise, most of the students strongly believe that business with societal causes bears testimony to ethical behavior. They further believe that business favors nepotism in recruiting employees and publicizes untrue, fabricated and exaggerated information in the media for the sake of capturing the market. Importantly, both the male and female respondents tend to have a similar opinion on these issues too. However, female respondents do not strongly agree with the male students on certain issues such as the introduction of ethical courses to create a change in the moral outlooks of the students, decisions taken by the management are honest, fair, and trustworthy, and compliance with legal requirements is more important than showing of ethical behavior. Besides, students do not have an unequivocal opinion on certain issues such as gender discrimination in the workplace, use of natural resources as free goods, the relationship between ethical practice and firms' profitability, and business managers' engagement with corruption, malpractices, and immoral activities to secure market share. 
Table 3. Mean Scores and T-Tests of Students' Responses on Ethical Questions

\begin{tabular}{|c|c|c|c|c|}
\hline Question & $\begin{array}{l}\text { Mean } \\
\text { Score }\end{array}$ & $\begin{array}{l}\text { Males' } \\
\text { Mean } \\
\text { Score }\end{array}$ & $\begin{array}{c}\text { Females' } \\
\text { Mean } \\
\text { Score }\end{array}$ & $\begin{array}{c}\text { t-Test } \\
\text { Score } \\
\text { Ho: } \mu=3 \text {, } \\
\text { Ha: } \mu \neq 3\end{array}$ \\
\hline $\begin{array}{l}\text { Greater business involvement with societal causes bears } \\
\text { testimony to ethical behavior. }\end{array}$ & 3.75 & 3.7 & 3.84 & $9.6627 *$ \\
\hline $\begin{array}{l}\text { Companies with a well-defined code of business conduct } \\
\text { will showcase more ethical behavior than companies } \\
\text { without it. }\end{array}$ & 4.17 & 4.2 & 4.13 & 16.6794* \\
\hline $\begin{array}{l}\text { Business people entrusted with decision-making are } \\
\text { honest, fair, just and trustworthy. }\end{array}$ & 3.1 & 3.18 & 2.98 & 1.2130 \\
\hline $\begin{array}{l}\text { Management takes stern action against unethical practices } \\
\text { as soon as these are reported and proved. }\end{array}$ & 3.53 & 3.5 & 3.58 & $5.5792 *$ \\
\hline $\begin{array}{l}\text { Adherence to ethical practices does not add profit to a } \\
\text { firm. }\end{array}$ & 2.06 & 1.99 & 2.18 & $-11.7089^{*}$ \\
\hline $\begin{array}{l}\text { Ethical behavior can be ensured by strict adherence to } \\
\text { laws and regulation. }\end{array}$ & 3.62 & 3.56 & 3.73 & $6.3022^{*}$ \\
\hline $\begin{array}{l}\text { Compliance with legal requirements is more important } \\
\text { than showing ethical behavior. }\end{array}$ & 3.05 & 3 & 3.15 & 0.5406 \\
\hline $\begin{array}{l}\text { The religious values can play an important role in the } \\
\text { conception and perfection of business ethics. }\end{array}$ & 4.5 & 4.58 & 4.35 & $24.5472 *$ \\
\hline $\begin{array}{l}\text { Businesses engage in corruption, malpractice, and } \\
\text { immoral activities by force (Intense competition, } \\
\text { unreasonable target, taking control of scarce resources), } \\
\text { not by will. }\end{array}$ & 2.69 & 2.8 & 2.49 & $-3.2174 *$ \\
\hline $\begin{array}{l}\text { Knowledge of business ethics is very important for the } \\
\text { owners and managers of the businesses and the future } \\
\text { business leaders also. }\end{array}$ & 4.68 & 4.64 & 4.75 & 28.2984* \\
\hline $\begin{array}{l}\text { Business students are unlikely to change their moral } \\
\text { outlook because they took an ethics course. }\end{array}$ & 2.95 & 2.94 & 2.96 & -0.5761 \\
\hline $\begin{array}{l}\text { The recruitment policy of the companies employs } \\
\text { nepotism and favoritism in selecting candidates. }\end{array}$ & 4.36 & 3.56 & 3.4 & $5.3556^{*}$ \\
\hline $\begin{array}{l}\text { Offering a gift or bribe to secure a business contract is not } \\
\text { unethical. }\end{array}$ & 1.68 & 1.77 & 1.51 & $-16.0607^{*}$ \\
\hline Businesses view natural resources (Air, Water, Land and & 2.7 & 2.68 & 2.73 & $-2.9124 *$ \\
\hline
\end{tabular}


other resources) as free and unlimited goods available for

their use.

Companies do not make gender discrimination and

provide safe and harassment free environment for female workers.

Businesses publicize untrue, fabricated and exaggerated

information about their product through an advertisement in media.

$* \mathrm{p}<0.05$

\section{Conclusions and Policy Remarks}

This paper investigates students' perceptions of business ethics in Bangladesh. Among other things, the results of the survey reveal several important aspects of the ethical practices in the business sector of Bangladesh. Firstly, enterprises need to have a well-defined code of conducts to ensure ethical conducts in business operation. It is also believed that the practice of ethical behavior can be excelled by strict adherence to laws and regulations. Secondly, a person's religious value can promote ethical behavior in business. Thirdly, enterprises involved in the social activities tend to be more ethical over others in taking appropriate management decisions. Fourthly, enterprises engage in malpractices intentionally, not by the pressure of competitive forces. In fact, they often publish fabricated and exaggerated information in media to keep intact market shares. Fifthly, enterprises usually put a value on political connections and references in the recruitment. They also make gender discrimination in recruitment and do not provide a safe and a harassment-free environment for the female workers. Finally, knowledge of business ethics for both the managers and owners can significantly improve the overall ethical behavior of an organization. This finding also shows the importance of introducing courses on business ethics in the university curriculum. As a whole, business students seem to attach utmost importance to ethical business practices in Bangladesh. By the results, the paper, however, puts following recommendations to improve enterprises' ethical behavior:

1) Enterprises should get engaged in as many social activities as possible within their affordable limits.

2) Enterprises should establish a well-defined code of conducts and government should enact required laws and regulations to check and control unethical practices.

3) Besides the well-defined code of conducts, enterprises should recognize the best ethical practice by introducing financial incentives and rewards.

4) Enterprises should be free from bias in decision making, and they should take stern action whenever an unethical practice comes into light.

5) Knowledge of business ethics should be checked through written and viva voce examinations while recruiting new blood.

6) Recruitment should be free from nepotism and political connections to welcome talents.

Published by SCHOLINK INC. 
7) Enterprises should provide a safe and a harassment-free environment, especially for female workers.

8) Enterprises should not publicize exaggerated information about their products in media and other communications channels.

9) Enterprises can arrange different workshops and seminars for the employees on a regular interval to uphold ethical practices in daily operations.

\section{References}

Abdolmohammadi, M. J., Gabhart, D. R. L., \& Reeves, M. F. (1997). Ethical cognition of business students individually and in groups. Journal of Business Ethics, 16(12-13), 1717-1725.

Ahmed, M. M., Chung, K. Y., \& Eichenseher, J. W. (2003). Business students' perception of ethics and moral judgment: A cross-cultural study. Journal of Business Ethics, 43(1-2), 89-102.

Alam, K. F. (1995). Attitudes towards business ethics of business students in Malaysia. Journal of Business Ethics, 14(4), 309-313.

Arlow, P., \& Ulrich, T. A. (1988). A longitudinal survey of business school graduates' assessments of business ethics. Journal of Business Ethics, 7(4), 295-302.

Barnett, J. H., \& Karson, M. J. (1989). Managers, values, and executive decisions: An exploration of the role of gender, career stage, organizational level, function and the importance of ethics, relationships and results in managerial decision-making. Journal of Business Ethics, 8(10), $747-771$

Beltramini, R. F., Peterson, R. A., \& Kozmetsky, G. (1984). Concern of college students regarding business ethics. Journal of Business Ethics, 3(3), 195-200.

Chung, K. Y., Eichenseher J. W., \& Taniguchi, T. (2008). Ethical perceptions of business students: Differences between East Asia and the USA and among "Confucian" cultures. Journal of Business Ethics, 79(1-2), 121-132.

Cohen, J., Pant, L., \& Sharp, D. (1998). The effect of gender and academic discipline diversity on the ethical evaluations, ethical intentions and ethical orientation of potential public accounting recruits. Accounting Horizons, 12(3), 250-270.

Cole, B. C., \& Smith, D. L. (1996). Perceptions of business ethics: Students vs. business people. Journal of Business Ethics, 15(8), 889-896.

Coutu, D. (2006). Leadership in literature. Harvard Business Review, 1(1), 1-3.

Curren, M. T., \& Harich, K. R. (1996). Business ethics: A comparison of business and humanities students and faculty. Journal of Education for Business, 72(1), 9-11.

Desplaces, D. E., Melchar, D. E., Beauvais, L. L., \& Bosco, S. M. (2007). The impact of business education on moral judgment competence: An empirical study. Journal of Business Ethics, 74(1), 73-87.

Ease of Doing Business Index. (2015). Retrieved from http://www.doingbusiness.org/rankings

Published by SCHOLINK INC. 
Fischer, M., \& Rosenzweig, K. (1995). Attitudes of students and accounting practitioners concerning the ethical acceptability of earnings management. Journal of Business Ethics, 14(6), 433-444.

Frank, R. H., Gilovich, T., \& Regan, D. T. (1993). Does studying economics inhibit cooperation? The Journal of Economic Perspectives, 7(2), 159-171.

Hollon, C. J., \& Ulrich, T. A. (1979). Personal business ethics: Managers vs. managers-to-be. Southern Business Review, 5, 17-22.

Hosmer, L. T. (1999). Somebody out there doesn't like us: A study of the position and respect of business ethics at schools of business administration. Journal of Business Ethics, 22(2), 91-106.

Kerr, D. S., \& Smith, L. M. (1995). Importance of and approaches to incorporating ethics into the accounting classroom. Journal of Business Ethics, 14(12), 987-995.

Lopez, Y. P., Rechner, P. L., \& Olson-Buchanan, J. B. (2005). Shaping ethical perceptions: An empirical assessment of the influence of business education, culture and demographic factors. Journal of Business Ethics, 60(4), 341-358.

Ludlum, M., \& Moskalionov, S. (2003). Comparative analysis of attitudes towards business ethics: USA and Russia. Economic Sciences: Scholar Papers, 2(12), 1-5.

Ludlum, M., Moskalionov, S., \& Ramachandran, V. (2013). Examining ethical behaviors by business students. American International Journal of Contemporary Research, 3(3), 13-21.

Lumsden, J., \& Fatoki, O. (2013). An investigation into the attitudes of business and non-business university students toward business ethics in South Africa. Anthropologist, 15(3), 249-253.

Ma, Z. Z. (2013). Business students cheating in classroom and their propensity to cheat in the real world: a study of ethicality and practicality in China. Asian Journal of Business Ethics, 2, 65-78.

McNichols, C. W., \& Zimmerer, T. W. (1985). Situational ethics: An empirical study of differentiators of student attitudes. Journal of Business Ethics, 4(3), 175-180.

Miesing, P., \& Preble, J. F. (1985). A comparison of five business philosophies. Journal of Business Ethics, 4(6), 465-476.

Mintz, S. M. (1997). Cases in Accounting Ethics and Professionalism. McGraw Hill Inc., New York, NY.

O’Clock, P., \& Okleshen, M. (1993). A comparison of ethical perceptions of business and engineering majors. Journal of Business Ethics, 12(9), 677-687.

Peppas, S. C., \& Diskin, B. A. (2001). College courses in ethics: Do they really make a difference? International Journal of Educational Management, 15(7), 347-353.

Preble, J. F., \& Reichel, A. (1988). Attitudes towards business ethics of future managers in the U.S. and Israel. Journal of Business Ethics, 7(12), 941-949.

Reiss, M. C., \& Mitra, K. (1998). The effects of individual difference factors on the acceptability of ethical and unethical workplace behaviors. Journal of Business Ethics, 17(14), 1581-1593.

Robin, D., \& Babin, L. (1997). Making sense of the research on gender and ethics in business: A critical analysis and extension. Business Ethics Quarterly, 7(4), 61-90. 
Roderick, J. C., Jelley, H. M., Cook, J. R., \& Forcht, K. A. (1991). The issue of white collar crime for collegiate schools of business. Journal of Education for Business, 66(5), 287-290.

Shurden, S. B., Santandreu, J., \& Shurden, M. C. (2010). How students perceptions of ethics can lead to future business behavior. Journal of Legal, Ethical and Regulatory Issues, 13(1), 117-127.

Small, M. W. (1992). Attitudes towards business ethics held by Western Australian students: A comparative study. Journal of Business Ethics, 11(10), 745-752.

Smith, A., \& Rogers, V. (2000). Ethics-related responses to specific situation vignettes: Evidence of gender-based differences and occupational socialization. Journal of Business Ethics, 28(1), 73-86.

Transparency International Bangladesh. (2015). Report Corruption Initiatives. Retrieved from http://www.ti-bangladesh.org/beta3/index.php/en/activities/4776-ti-bangladesh-launches-online-re port-corruption-initiative

World Bank. (2013). Enterprise Survey 2013. Bangladesh. Retrieved from http://www.enterprisesurveys.org/data/exploreeconomies/2013/bangladesh

Zeman, N. (1989, October 30). Hey ma, get me a lawyer! Newsweek, 114(18), 10. 